Jurnal Ekonomi, Bisnis dan Akuntansi (JEBA) Volume 22 No 3 Tahun 2020

\title{
ANALISIS FAKTOR YANG MEMPENGARUHI PRAKTIK AKUNTANSI PADA USAHA KECIL DAN MENENGAH DI KABUPATEN KEBUMEN
}

\author{
Januaristie Rossan Vilayanti ${ }^{*}$, Bambang Setia Budhi' ${ }^{1}$, Rini Widianingsih ${ }^{1}$ \\ 1Jurusan Akuntansi, Fakultas Ekonomi dan Bisnis, Universitas Jenderal Soedirman, Jawa Tengah, \\ Indonesia \\ *Email corresponding: ri3n.wibowo@gmail.com
}

\begin{abstract}
ABSTRAK
Penelitian ini bertujuan untuk mengetahui faktor yang terbentuk pada praktik akuntansi UKM. Penelitian ini merupakan penelitian kuantitatif dengan data primer berupa hasil kuesioner dan hasil wawancara yang dilakukan peneliti kepada pelaku UKM di Kabupaten Kebumen. Populasi dalam penelitian ini adalah seluruh Usaha Kecil dan Menengah (UKM) yang memiliki Izin Usaha Industri (IUI) yang sekaligus terdaftar di Dinas Koperasi UMKM Sampel dari penelitian ini 78 UKM, diperoleh dengan menggunakan teknik purposive sampling. Teknik analisis yang digunakan adalah analisis faktor. Hasil penelitian ini menunjukkan terdapat 3 faktor yang terbentuk dari analisis faktor. Faktor I diberi nama Faktor Pengetahuan dan Kepribadian, terdiri dari variabel pendidikan, pelatihan akuntansi, pemberian informasi praktik akuntansi, teknologi informasi, minat, motivasi dan kepribadian. Faktor II diberi nama Faktor Kegunaan, terdiri dai variabel cost benefit dan variabel tingkat persaingan. Faktor III diberi nama Faktor Kredit, terdiri dari satu variabel saja yakni variabel kredit. Dua variabel yakni variabel ukuran perusahaan dan umur usaha dikeluarkan karena memiliki nilai MSA $<0,5$.
\end{abstract}

Kata Kunci: Analisis Faktor, Praktik Akuntansi, UKM.

\begin{abstract}
This study aims to determine the factors formed in the accounting practices of SMEs. This research is a quantitative study with primary data in questionnaires and interviews conducted by researchers with SMEs in Kebumen Regency. The population in this study were all Small and Medium Enterprises (SMEs) that had Industrial Business Permits (IUI), which were also registered at the SMEs Cooperative Office. The sample of this study was 78 SMEs, obtained using the purposive sampling technique. The analysis technique used is factor analysis. The results of this study indicate that there are three factors formed from factor analysis. The first factor is named the Knowledge and Personality Factors, consisting of the variables of education, accounting training, providing information on accounting practices, information technology, interests, motivation, and personality. The second factor is named the Usefulness Factor, consisting of the cost-benefit variable and the level of competition variable. Factor III is called Credit Factor, consisting of only one variable, namely the credit variable. Two variables, namely company size and age of business were excluded because they had an MSA value $<0.5$
\end{abstract}

Keyword: Factor Analysis, Accounting Practices, SMEs. 


\section{PENDAHULUAN}

Usaha Mikro, Kecil dan Menengah (UMKM) memainkan peran penting dalam pertumbuhan ekonomi dan pembangunan yang berkesinambungan dari setiap bangsa (Moore et al., 2001). Meskipun kecil dalam skala omzet, asset, dan pekerja, namun karena jumlahnya yang cukup banyak, peranan UMKM cukup penting dalam menunjang perekonomian suatu negara. Oleh sebab itu, saat ini pemerintah sedang gencar memaksimalkan potensi bisnis pada UMKM di berbagai daerah. Alasannya, semakin banyak wirausahawan yang ada di suatu negara atau daerah maka akan semakin baik dan kokohnya perekonomian di negara atau daerah tersebut karena sumber daya lokal, pekerja lokal, dan pembiayaan lokal dapat terserap dan bermanfaat secara optimal.

Penelitian ini hanya menggunakan sampel berupa Usaha Kecil dan Menengah saja dengan alasan karena pada saat ini masih banyak sekali Usaha Kecil dan Menengah (UKM) yang tidak menerapkan praktik akuntansi pada usahanya, apalagi dengan usaha mikro. UKM yang memiliki asset cukup besar pun masih banyak yang belum menerapkan praktik akuntansi, apalagi dengan usaha mikro yang memiliki asset kecil dan penjualan yang masih relatif kecil. Hal itu didukung dengan penelitian yang dilakukan oleh Gilbert Kwabena Amoako (2013) bahwa masih banyak usaha kecil dan menengah (UKM) yang tidak menerapkan praktik akuntansi dengan alasan utamanya adalah praktik akuntansi tidak membawa manfaat pada usahanya.

Dalam menjalankan aktivitas usaha seringkali pengelola UKM merasa kesulitan dalam melakukan pencatatan terhadap apa yang terjadi pada operasional usahanya (Hidayat, 2008). Kesulitan itu menyangkut aktivitas dan penilaian atas hasil yang dicapai oleh setiap usaha. Apalagi jika harus dilakukan pengukuran dan penilaian atas aktivitas yang terjadi dalam kegiatan usaha. Pencatatan dilakukan hanya dengan menghitung selisih antara uang masuk dengan uang yang keluar, tanpa melihat pengeluaran uang itu untuk atau dari alokasi kegiatan usaha ataupun non usaha. Seringkali dalam skala usaha kecil menengah hasil usaha dikatakan bagus jika pendapatan sekarang lebih tinggi dibanding dengan pendapatan sebelumnya. Padahal indikator dari keberhasilan tidak hanya diukur dari pendapatan saja, diperlukan pengukuran dan pengelompokan atas transaksi atau kegiatan yang terjadi serta pengikhtisaran transaksitransaksi tersebut.

Informasi akuntansi sangat bermanfaat bagi UKM, karena merupakan alat yang digunakan oleh pengguna informasi untuk pengambilan keputusan (Holmes dan Nicholls, 1988). Informasi akuntansi dapat digunakan untuk mengukur dan mengkomunikasikan informasi keuangan perusahaan yang sangat diperlukan oleh pihak manajemen dalam merumuskan berbagai keputusan untuk memecahkan permasalahan yang dihadapi. Selain itu informasi akuntansi juga berguna dalam rangka menyusun berbagai gambaran keuangan, misalnya proyeksi kebutuhan uang kas di masa yang akan datang, mengontrol biaya, mengukur dan meningkatkan produktivitas dan memberikan dukungan terhadap proses produksi.

Kabupaten Kebumen merupakan salah satu kabupaten yang memiliki UMKM dengan jumlah yang cukup banyak. Berdasarkan data dari Dinas Koperasi dan UMKM Kabupaten Kebumen menunjukkan jumlah UMKM di Kabupaten Kebumen sebanyak 43.132 buah. Sebagian besar dari UMKM tersebut telah memiliki izin usaha yang resmi. Terkait pelayanan ijin UMKM, berdasarkan data yang terdapat di situs resmi Dinas Koperasi dan UMKM Provinsi Jawa Tengah, Kabupaten Kebumen terdata menjadi daerah terbanyak yang mengajukan izin usaha, yakni sebanyak 8.954 UMKM. Hingga akhir Desember 2016 lalu, sebanyak 9.150 UMKM telah memiliki izin usaha.

Berlawanan dengan hal itu, ternyata masih banyak pelaku usaha di Kabupaten Kebumen yang belum melakukan pencatatan. Padahal, pencatatan dibutuhkan untuk mengukur kinerja 
sebuah perusahaan. Tidak dilakukannya pencatatan dan pembuatan laporan keuangan membuat beberapa pengajuan kredit yang dilakukan oleh mereka ditolak oleh pihak perbankan. Pihak perbankan sangat membutuhkan laporan keuangan para calon nasabahnya untuk melihat kinerja dari perusahaan tersebut. Jika perusahaan tidak potensial, pihak perbankan tidak dapat mengambil resiko untuk menerima pengajuan kredit mereka dan memilih untuk menolaknya.

Masih sedikitnya pelaku usaha yang melakukan pencatatan membuat peneliti tertarik untuk menyelidiki faktor-faktor apa sajakah yang mempengaruhi praktik akuntansi pada Usaha Kecil Menengah (UKM) di Kabupaten Kebumen. Terdapat beberapa penelitian terdahulu yang meneliti tentang ketersediaannya informasi pada Usaha Kecil Menengah (UKM). Berbagai penelitian menunjukkan adanya pengaruh sejumlah faktor terhadap ketersediaan informasi pada UKM. Penelitian yang dilakukan oleh Solovida (2003) diperoleh kesimpulan bahwa terdapat pengaruh positif pada semua variabel yang diteliti (skala usaha, masa memimpin, umur usaha, pendidikan pemilik, serta budaya organisasi) terhadap penyiapan dan penggunaan informasi akuntansi pada perusahaan kecil dan menengah.

Selanjutnya, berdasarkan penelitian Holmes dan Nicholls (1989) yang berjudul "Modelling the Accounting Information Requirements of Small Bussniness" menunjukkan bahwa ukuran bisnis, masa manajemen memimpin operasional usaha, penddikan manajer atau pemilik usaha mempengaruhi kebutuhan informasi akuntansi. Sedangkan penelitian yang dilakukan oleh Pratiwi (2008) menunjukkan bahwa hanya pemahaman teknologi informasi yang berpengaruh terhadap kebutuhan SAK ETAP bagi UKM. Variabel tingkat pendidikan pemilik dan karakteristik kualitatif laporan keuangan tidak berpengaruh terhadap kebutuhan SAK ETAP bagi UKM.

Penelitian Zamani (2010) menunjukkan bahwa motivasi, minat dan kepribadian secara simultan berpengaruh terhadap persepsi implementasi Standar Akuntansi Keuangan Entitas Tanpa Akuntabilitas Publik (SAK ETAP). Penelitian selanjutnya dilakukan oleh Rudiantoro dan Sylvia (2011) menunjukkan bahwa pelaku UMKM memiliki persepsi bahwa pembukuan dan pelaporan keuangan merupakan hal yang cukup penting dalam pertumbuhan dan perkembangan usaha. Faktor ukuran usaha berpengaruh positif terhadap persepsi pentingnya pembukuan dan pelaporan keuangan sedangkan lama usaha berpengaruh negatif terhadap persepsi. Faktor jenjang pendidikan terakhir dan latar belakang pendidikan tidak berpengaruh signifikan terhadap pemahaman SAK ETAP serta kualitas laporan keuangan tidak berpengaruh terhadap besarnya kredit.

Wijayanti (2015) menemukan bahwa adanya pengaruh jenjang pendidikan, latar belakang pendidikan, masa tugas, pemberian informasi, dan sosialisasi terhadap implementasi SAK ETAP di Koperasi. Sedangkan berdasarkan penelitian dari Hiziatun (2014), masa memimpin manajer dan keterlibatan keluarga tidak berpengaruh terhadap ketersediaan informasi UMKM di Kabupaten Purbalingga. Hanya ukuran perusahaan, umur perusahaan, dan pelatihan akuntansi yang berpengaruh terhadap ketersediaan informasi akuntansi.

Penelitian yang dilakukan oleh Gilbert Kwabena Amoako (2013) yang berjudul "Accounting Practices of SMEs: A Case Study of Kumasi Metropolis in Ghana" menunjukkan bahwa alasan para pelaku usaha tidak melakukan pencatatan adalah mereka merasa tidak adanya manfaat melakukan pencatatan, pendidikan rendah, pemahaman manajer terhadap akuntansi rendah, tidak adanya pelatihan akuntansi, adanya biaya apabila melakukan pencatatan dan usia kerja manajer/pemilik. Penelitian yang dilakukan oleh Nelson Maseko dan Onias Manyani (2011) menunjukkan bahwa pengetahuan akuntansi rendah dan terdapat biaya untuk menyewa akuntan dan tidak adanya pelatihan akuntansi. Menurut penelitian yang dilakukan oleh I Made Narsa dkk (2012) yang berjudul "Mengungkap Kesiapan UMKM dalam Implementasi Standar Akuntansi 
Keuangan Entitas Tanpa Akuntabilitas Publik (PSAK-ETAP) untuk Meningkatkan Akses Modal Perbankan" menghasilkan ditemukannya kendala UMKM adalah tidak memiliki laporan keuangan sesuai dengan standar SAK-ETAP dan UMKM yang memiliki catatan keuangan yang baik mempunyai perkembangan yang lebih pesat dibandingkan dengan UMKM lainnya meskipun usia pendiriannya sama, bahkan lebih muda dari beberapa UMKM yang lainnya. Salah satu yang mendorong kemajuan UMKM tersebut adalah kemampuan mengakses kredit dari perbankan, sehingga masalah kesulitan permodalan dapat diatasi.

Berdasarkan latar belakang yang telah diuraikan di atas, maka masalah penelitian ini adalah masih banyak faktor-faktor yang diperkirakan dapat menjelaskan tentang praktik akuntansi pada Usaha Kecil dan Menengah (UKM). Penelitian ini menggunanakan analisis faktor untuk mengidentifikasi faktor-faktor yang diperkirakan mempengaruhi praktik akuntansi pada UKM di Kabupaten Kebumen. Oleh sebab itu, peneliti tertarik untuk mengambil judul penelitian "Analisis Faktor yang Mempengaruhi Praktik Akuntansi pada Usaha Kecil dan Menengah di Kabupaten Kebumen".

\section{Metode Penelitian}

Jenis penelitian ini adalah penelitian kuantitatif dengan menggunakan kuesioner sebagai sumber data. Populasi dalam penelitian ini adalah seluruh Usaha Kecil dan Menengah (UKM) memiliki Izin Usaha Industri (IUI) yang sekaligus terdaftar di Dinas Koperasi UMKM Kabupaten Kebumen. Jumlah populasi pada penelitian ini adalah 811 UKM. Sampel dalam penelitian ini ditentukan dengan metode purposive sampling dengan kriteria sebagai berikut: 1) UKM memiliki jumlah tenaga kerja 5 (lima) sampai 19 (sembilan belas) orang yang merupakan kategori sebagai usaha kecil menurut Undang-Undang Nomor 20 tahun 2008; 2) UKM memiliki jumlah tenaga kerja 20 (dua puluh) sampai 99 (sembilan puluh sembilan) yang merupakan kategori sebagai usaha menengah menurut Undang-Undang Nomor 20 tahun 2008; 3) UKM berjenis usaha manufaktur; 4) UKM memiliki umur usaha minimal 5 tahun; 5) UKM tersebut masih aktif beroperasi; 6) UKM nyata adanya dan memiliki alamat yang jelas dalam daftar.

Model Penelitian

\begin{tabular}{|l|l|}
\hline Pendidikan Pemilik & \\
Ukuran Perusahaan & \\
Umur Usaha & \\
Pelatihan Akuntansi & \\
Pengetahuan Akuntansi & \\
Pemberian Inf Praktik Akt \\
Teknologi Informasi \\
Kredit \\
Minat \\
Motivasi \\
Kepribadian \\
Komitmen Organisasi \\
Cost Benefit \\
Tingkat Persaingan \\
\hline
\end{tabular}

Metode analisis data dalam penelitian ini: 1) Uji validitas pada penelitian ini menggunakan rumus korelasi Product Moment; 2) Uji reliabilitas dalam penelitian ini menggunakan uji reliabilitas teknik Cronbach Alpha. Kriteria reliabilitas dikatakan reliable apabila koefisien alpha lebih besar dari 0,6 (Ghozali, 2006); 3) Uji statistik deskriptif digunakan untuk mendeskripsikan variabel-variabel dalam penelitian ini. Alat analisis yang digunakan adalah rata-rata (mean), 
standar deviasi, maksimum dan minimum (Ghozali, 2006). Analisis faktor merupakan suatu teknik untuk menganalisis tentang saling ketergantungan (interdependence) dari beberapa variabel secara simultan dengan tujuan untuk menyederhanakan dari bentuk hubungan antara beberapa variabel yang diteliti menjadi sejumlah faktor yang lebih sedikit daripada variabel yang diteliti, yang berarti dapat juga menggambarkan tentang struktur data dari suatu penelitian (Suliyanto, 2005).

Persamaan atau rumus analisis faktor adalah sebagai berikut:

$$
X_{(p \times 1)}-\mu_{(p \times 1)}=L_{(p \times m)} F_{(m \times 1)}+\varepsilon_{(p \times 1)}
$$

Dimana:

$\mathrm{X}=$ vector variabel asal $\left(\mathrm{X}_{1}, \mathrm{X}_{2}, \mathrm{X}_{3}, \ldots, \mathrm{Xp}\right)$

$\mu \quad=$ vector rata-rata variabel awal

$\mathrm{L} \quad=$ matriks beban faktor yang merefleksikan pentingnya faktor bersama, dimana $\mathrm{L}_{\mathrm{ij}}$ adalah nilai beban faktor dari variabel ke-i pada faktor ke-j dengan $i=1,2$, $3, \ldots, \mathrm{p}$ dan $j=1,2,3, \ldots, \mathrm{m}$

$\mathrm{F} \quad=$ vector faktor bersama-sama

$\varepsilon=$ vector faktor khusus atau galat

Tahapan dalam melaksanakan analisis faktor eksploratori dalam penelitian ini mengacu kepada Suliyanto (2005):a) Menghitung matriks korelasi antar semua variable. Untuk melakukan analisis faktor, jumlah sampel minimal adalah empat sampai lima kali jumlah variabel. Untuk mengetahui kecukupan sampel dan menguji ketepatan model faktor, uji statistic yang digunakan adalah Kaiser Meyer Oikin (KMO) dan Barlett's Test Spherricity (Supranto, 2004, 122). Kaiser Meyer Oikin (KMO) measure of sampling adequancy adalah indeks yang digunakan untuk menguji ketepatan analisis faktor. Metode ini paling banyak digunakan untuk melihat syarat kecukupan data untuk analisis faktor. Metode KMO ini mengukur kecukupan sampling secara menyeluruh dan mengukur kecukupan sampling untuk setiap indikator. Adapun formula untuk menghitung KMO sebagai berikut (Widarjono, 2015):

$$
\mathrm{KMO}=\frac{\sum \sum r_{i j} 2}{\sum \sum r_{i j} 2+\sum \sum a_{i j} 2}
$$

Dimana:

$\mathrm{r}^{\mathrm{i}_{\mathrm{ij}}} \quad=$ koefisien korelasi sederhana

$\mathrm{a}^{2}{ }_{\mathrm{ij}} \quad=$ koefisien korelasi parsial

Untuk dapat melakukan analisis faktor, syaratnya adalah KMO Measure Sampling od Adequancy harus di atas 0,5 (KMO>0,5).

Ekstraksi factor

Pada tahap ini akan dilakukan proses inti dari analisi faktor yaitu melakukan ekstraksi terhadap sekumpulan variabel yang ada KMO $>0,5$ sehingga terbentuk satu atau lebih faktor. Metode yang digunakan adalah Principal Component Analysis (PCA). Principal Component Analysis merupakan model dalam analysis faktor yang tujuannya untuk melakukan prediksi terhadap sejumlah faktor yang dihasilkan.

Variabel-variabel yang diperoleh dengan menggunakan analisis faktr dengan model PCA dapat dituliskan sebagai berikut (Suliyanto, 2005) :

Dimana :

$$
F M=l_{m 1} X_{1}+l_{m 2} X_{2}+\ldots+l_{m p} X_{p}
$$

$$
\begin{aligned}
& \mathrm{F}=\text { faktor principal component (unobservable) } \\
& \mathrm{X}=\text { variabel yang diteliti (observable) } \\
& \mathrm{l}=\text { bobot dari kombinasi linear (loadings) }
\end{aligned}
$$


Penentuan jumlah faktor yang diperlukan untuk mewakili variabel-variabel yang akan dianalisis didasarkan pada besarnya eigen value serta presentase total variannya. Hanya faktor yang memiliki eigen value sama atau lebih besar dari satu yang dipertahankan dalam model analisis faktor. Untuk faktor yang memiliki eigen value kurang dari satu maka dikeluarkan dari model dan tidak diikutsertakan pada uji berikutnya.

\section{$\underline{\text { Rotasi faktor }}$}

Dalam analisis rotasi faktor dilakukan dengan metode rotasi varimax. Metode varimax mengasumsikan bahwa hubungan antarvariabel tidak ada atau korelasi antar faktor adalah nol. Asumsi tersebut sebenarnya kurang realistis, namun metode ini lebih stabil. Metode ini berusaha meminimalkan (membuat sedikit mungkin) banyaknya variabel dengan muatan tinggi (high loading) pada satu faktor, dengan demikian memudahkan pembuatan interpretasi mengenai faktor (Supranto, 2004:132).

Interpretasi factor

Interpretasi faktor dilakukan dengan mengklasifikasikan variabel berdasarkan factor loading $>0,50$ dan memberikan nama pada faktor yang terbentuk.

\section{Model fit (Ketepatan Model)}

Tahap akhir dari ananlisis faktor adalah mengetahui ketepatan dalam memilih teknik analisis faktor antara principal component analysis dan maximum likelihood dengan melihat jumlah residual (perbedaan) antara korelasi yang diamati dengan korelasi yang diproduksi. Semakin kecil persentase nilai residual (dalam hal ini adalah nilai root mean square error $=$ RMSE), maka semakin tepat penentuan teknik tersebut.

\section{Uji Validitas dan Reliabilitas Kuesioner}

Uji validitas dapat dilakukan dengan melakukan korelasi bivariat antara masing-masing skor indicator dengan total skor konstruk. Suatu kuesioner dikatakan valid jika pertanyaan pada

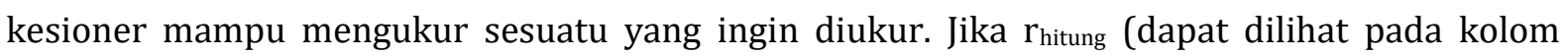
corrected item-ctotal correlation) lebih besar dari rtabel dan nilai $r$ adalah positif, maka item pada kuesioner dikatakan valid.

Uji yang digunakan pada penelitian ini adalah menggunakan rumus korelasi Product Moment

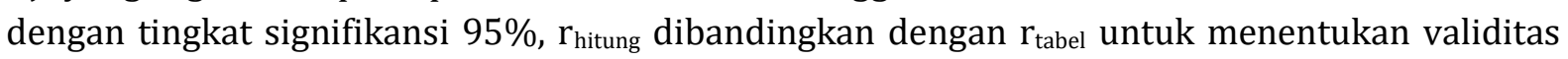
kuesioner yang digunakan (Suliyanto, 2005). Uji validitas digunakan untuk menguji masingmasing item pertanyaan yang digunakan dalam pertanyaan ini, dimana keseluruhan variabel penelitian memuat 49 pertanyaan. Dengan Degree of freedom $(\mathrm{df})=(30-2)$ dan tingkat signifikansi $95 \%$ diperoleh $r_{\text {tabel }}$ sebesar 0,374 . Berikut adalah tabel ringkasan dari pengujian validitas pada lampiran 5 .

\section{Tabel 1. Hasil Pengujian Validitas Pemberian Informasi Praktik Akuntansi}

\begin{tabular}{cccc}
\hline Item Pernyataan & $\mathbf{r}_{\text {hitung }}$ & $\mathbf{r}_{\text {tabel }}$ & Keterangan \\
\hline 1 & 0,837 & 0,374 & Valid \\
2 & 0,852 & 0,374 & Valid \\
3 & 0,863 & 0,374 & Valid \\
4 & 0,863 & 0,374 & Valid \\
\hline
\end{tabular}

Sumber: Hasil Output SPSS yang diolah

Tabel 1 menjelaskan bahwa ke-4 item pernyataan variabel pemberian informasi praktik akuntansi pada kuesioner yang telah dibagikan memiliki $r_{\text {hitung }}>r_{\text {tabel }}$ sehingga seluruh item pernyataan dinyatakan valid dan dapat digunakan sebagai alat pengumpulan data.

Tabel 2. Hasil Pengujian Validitas Teknologi Informasi

\begin{tabular}{cccc}
\hline Item Pertanyaan & $\mathbf{r}_{\text {hitung }}$ & $\mathbf{r}_{\text {tabel }}$ & Keterangan \\
\hline
\end{tabular}




\begin{tabular}{llll}
\hline 1 & 0,665 & 0,374 & Valid \\
2 & 0,697 & 0,374 & Valid \\
3 & 0,784 & 0,374 & Valid \\
4 & 0,913 & 0,374 & Valid \\
\hline
\end{tabular}

Sumber: Hasil Output SPSS yang diolah

Tabel 2 menjelaskan bahwa ke-4 item pertanyaan variabel teknologi informasi pada kuesioner yang telah dibagikan memiliki $r_{\text {hitung }}>r_{\text {tabel }}$ sehingga seluruh item pernyataan dinyatakan valid dan dapat digunakan sebagai alat pengumpulan data.

Tabel 3. Hasil Pengujian Validitas Kredit

\begin{tabular}{cccc}
\hline Item Pernyataan & $\mathbf{r}_{\text {hitung }}$ & $\mathbf{r}_{\text {tabel }}$ & Keterangan \\
\hline 1 & 0,665 & 0,374 & Valid \\
2 & 0,697 & 0,374 & Valid \\
3 & 0,784 & 0,374 & Valid \\
4 & 0,913 & 0,374 & Valid \\
\hline
\end{tabular}

Sumber: Hasil Output SPSS yang diolah

Tabel 3 menunjukkan bahwa ke-4 item pernyataan variabel kredit pada kuesioner yang telah dibagikan memiliki $r_{\text {hitung }}>r_{\text {tabel }}$ sehingga seluruh item pernyataan dinyatakan valid dan dapat digunakan sebagai alat pengumpulan data.

Tabel 4. Hasil Pengujian Validitas Minat

\begin{tabular}{cccc}
\hline Item Pernyataan & $\mathbf{r}_{\text {hitung }}$ & $\mathbf{r}_{\text {tabel }}$ & Keterangan \\
\hline 1 & 0,813 & 0,374 & Valid \\
2 & 0,786 & 0,374 & Valid \\
3 & 0,853 & 0,374 & Valid \\
4 & 0,820 & 0,374 & Valid \\
5 & 0,854 & 0,374 & Valid \\
\hline
\end{tabular}

Sumber: Hasil Output SPSS yang diolah

Tabel 4 menunjukkan bahwa ke-5 item pernyataan variabel minat pada kuesioner yang telah dibagikan memiliki $r_{\text {hitung }}>r_{\text {tabel }}$ sehingga seluruh item pernyataan dinyatakan valid dan dapat digunakan sebagai alat pengumpulan data.

Tabel 5. Hasil Pengujian Validitas Motivasi

\begin{tabular}{cccc}
\hline Item Pernyataan & $\mathbf{r}_{\text {hitung }}$ & $\mathbf{r}_{\text {tabel }}$ & Keterangan \\
\hline 1 & 0,795 & 0,374 & Valid \\
2 & 0,851 & 0,374 & Valid \\
3 & 0,863 & 0,374 & Valid \\
4 & 0,709 & 0,374 & Valid \\
5 & 0,924 & 0,374 & Valid \\
\hline
\end{tabular}

Sumber: Hasil Output SPSS yang diolah

Tabel 5 menunjukkan bahwa ke-5 item pernyataan variabel motivasi pada kuesioner yang telah dibagikan memiliki $r_{\text {hitung }}>r_{\text {tabel }}$ sehingga seluruh item pernyataan dinyatakan valid dan dapat digunakan sebagai alat pengumpulan data.

Tabel 6. Hasil Pengujian Validitas Kepribadian

$\begin{array}{llll}\text { Item Pernyataan } & \mathbf{r}_{\text {hitung }} & \mathbf{r}_{\text {tabel }} & \text { Keterangan }\end{array}$




\begin{tabular}{cccc}
\hline 1 & 0,554 & 0,374 & Valid \\
2 & 0,398 & 0,374 & Valid \\
3 & 0,499 & 0,374 & Valid \\
4 & 0,540 & 0,374 & Valid \\
5 & 0,463 & 0,374 & Valid \\
6 & 0,564 & 0,374 & Valid \\
7 & 0,602 & 0,374 & Valid \\
8 & 0,416 & 0,374 & Valid \\
9 & 0,668 & 0,374 & Valid \\
10 & 0,552 & 0,374 & Valid \\
11 & 0,444 & 0,374 & Valid \\
\hline
\end{tabular}

Sumber: Hasil Output SPSS yang diolah

Tabel 6 menunjukkan bahwa ke-11 item pernyataan variabel kepribadian pada kuesioner yang telah dibagikan memiliki $r_{\text {hitung }}>r_{\text {tabel }}$ sehingga seluruh item pernyataan dinyatakan valid dan dapat digunakan sebagai alat pengumpulan data.

Tabel 7. Hasil Pengujian Validitas Komitmen Organisasi

\begin{tabular}{cccc} 
Item Pernyataan & $\mathbf{r}_{\text {hitung }}$ & $\mathbf{r}_{\text {tabel }}$ & Keterangan \\
\hline 1 & 0,760 & 0,374 & Valid \\
2 & 0,829 & 0,374 & Valid \\
3 & 0,865 & 0,374 & Valid \\
4 & 0,819 & 0,374 & Valid \\
5 & 0,695 & 0,374 & Valid \\
6 & 0,755 & 0,374 & Valid \\
\hline
\end{tabular}

Sumber: Hasil Output SPSS yang diolah

Tabel 7 menunjukkan bahwa ke-6 item pernyataan variabel komitmen organisasi pada kuesioner yang telah dibagikan memiliki $r_{\text {hitung }}>r_{\text {tabel }}$ sehingga seluruh item pernyataan dinyatakan valid dan dapat digunakan sebagai alat pengumpulan data.

Tabel 8. Hasil Pengujian Validitas Cost and Benefit

\begin{tabular}{cccc}
\hline Item Pernyataan & $\mathbf{r}_{\text {hitung }}$ & $\mathbf{r}_{\text {tabel }}$ & Keterangan \\
\hline 1 & 0,696 & 0,374 & Valid \\
2 & 0,720 & 0,374 & Valid \\
3 & 0,595 & 0,374 & Valid \\
4 & 0,538 & 0,374 & Valid \\
5 & 0,803 & 0,374 & Valid \\
\hline
\end{tabular}

Sumber: Hasil Output SPSS yang diolah

Tabel 8 menunjukkan bahwa ke-5 item pernyataan variabel cost and benefit pada kuesioner yang telah dibagikan memiliki $r_{\text {hitung }}>r_{\text {tabel }}$ sehingga seluruh item pernyataan dinyatakan valid dan dapat digunakan sebagai alat pengumpulan data.

Tabel 9. Hasil Pengujian Validitas Tingkat Persaingan

\begin{tabular}{cccc}
\hline Item Pernyataan & $\mathbf{r}_{\text {hitung }}$ & $\mathbf{r}_{\text {tabel }}$ & Keterangan \\
\hline 1 & 0,627 & 0,374 & Valid \\
2 & 0,462 & 0,374 & Valid \\
3 & 0,772 & 0,374 & Valid \\
4 & 0,714 & 0,374 & Valid \\
5 & 0,768 & 0,374 & Valid \\
\hline
\end{tabular}


Sumber: Hasil Output SPSS yang diolah

Tabel 9 menunjukkan bahwa ke-5 item pernyataan variabel tingkat persaingan pada kuesioner yang telah dibagikan memiliki $r_{\text {hitung }}>r_{\text {tabel }}$ sehingga seluruh item pernyataan dinyatakan valid dan dapat digunakan sebagai alat pengumpulan data.

Uji Reliabilitas

Uji reliabilitas dalam penelitian ini menggunakan rumus Cronbach's Alpha. Suatu instrumen penelitian dapat dinyatakan reliabel jika nilai $r_{\text {hitung }}>0,60$. Berikut adalah hasil uji reliabilitas.

Tabel 10. Hasil Pengujian Reliabilitas Kuesioner

\begin{tabular}{cccc}
\hline Vari-abel & $\begin{array}{c}\text { Koefisien Cronbach } \\
\text { Alpha }\end{array}$ & $\begin{array}{c}\text { Cronbach Alpha } \\
\text { Minimum }\end{array}$ & Ket \\
\hline $\mathrm{X}_{6}$ & 0,871 & 0,60 & Valid \\
$\mathrm{X} 7$ & 0,902 & 0,60 & Valid \\
$\mathrm{X} 8$ & 0,772 & 0,60 & Valid \\
$\mathrm{X}_{9}$ & 0,5881 & 0,60 & Valid \\
$\mathrm{X}_{10}$ & 0,885 & 0,60 & Valid \\
$\mathrm{X}_{11}$ & 0,682 & 0,60 & Valid \\
$\mathrm{X}_{12}$ & 0,873 & 0,60 & Valid \\
$\mathrm{X}_{13}$ & 0,703 & 0,60 & Valid \\
$\mathrm{X}_{14}$ & 0,684 & 0,60 & Valid \\
\hline
\end{tabular}

Sumber: Hasil Output SPSS yang diolah

\section{HASIL DAN PEMBAHASAN}

Membuat Matriks Korelasi Antar Semua Variabel

Berikut adalah tabel hasil pengujian measurement of sampling adequacy I.

Tabel 11. Nilai Measurement of Sampling Adequacy I

\begin{tabular}{llc}
\hline No & \multicolumn{1}{c}{ Variabel-variabel yang diteliti } & Nilai MSA \\
\hline 1 & Pendidikan Pemilik & 0,848 \\
2 & Ukuran Perusahaan & $\mathbf{0 , 4 5 3}$ \\
3 & Umur Usaha & $\mathbf{0 , 2 9 5}$ \\
4 & Pelatihan Akuntansi & 0,822 \\
5 & Pengetahuan Akuntansi & 0,596 \\
6 & Pemberian Informasi Praktik Akuntansi & 0,778 \\
7 & Teknologi Informasi & 0,871 \\
8 & Kredit & 0,609 \\
9 & Minat & 0,731 \\
10 & Motivasi & 0,760 \\
11 & Kepribadian & 0,794 \\
12 & Komitmen Organisasi & 0,831 \\
13 & Cost Benefit & 0,516 \\
14 & Tingkat Persaingan & 0,690 \\
\hline
\end{tabular}

Berdasarkan hasil perhitungan MSA pada tabel di atas, diketahui ada dua indikator yang tidak memenuhi syarat atau nilai MSA $<0,5$ yaitu variabel ukuran perusahaan dengan MSA = 0,453 dan variabel umur usaha dengan nilai MSA $=0,295$ sehingga kedua variabel tersebut harus dikeluarkan. Peneliti menemukan bahwa ukuran perusahaan dan umur usaha tidak berpengaruh terhadap praktik akuntansi. 
Yang pertama kali harus dikeluarkan dari analisis faktor adalah variabel yang mempunyai nilai MSA paling kecil.dan harus dikeluarkan terlebih dahulu. Berdasarkan hasil pengujian kedua pada lampiran 7 didapat hasil sebagai berikut:

Tabel 12. Nilai Measurement of Sampling Adequacy II

\begin{tabular}{llc}
\hline No & \multicolumn{1}{c}{ Variabel-variabel yang diteliti } & Nilai MSA \\
\hline 1 & Pendidikan Pemilik & 0,843 \\
2 & Ukuran Perusahaan & $\mathbf{0 , 4 4 9}$ \\
3 & Pelatihan Akuntansi & 0,825 \\
4 & Pengetahuan Akuntansi & 0,633 \\
5 & Pemberian Informasi Praktik Akuntansi & 0,821 \\
6 & Teknologi Informasi & 0,880 \\
7 & Kredit & 0,613 \\
8 & Minat & 0,752 \\
9 & Motivasi & 0,777 \\
10 & Kepribadian & 0,799 \\
11 & Komitmen Organisasi & 0,845 \\
12 & Cost Benefit & 0,512 \\
13 & Tingkat Persaingan & 0,713 \\
\hline
\end{tabular}

Sumber: Hasil Output SPSS yang diolah

Berdasarkan hasil analisis dari pengujian kedua, nilai KMO MSA sebesar 0,763 dan Barlett's test juga menunjukkan signifikan dengan nilai 331,023 (sig. = 0,000). Sedangkan nilai MSA pada variabel ukuran perusahaan menunjukkan MSA $<0,5$, sehingga proses analisis faktor bisa dilanjutkan dengan mengeluarkan variabel ukuran perusahaan. Setelah variabel ukuran perusahaan, berdasarkan hasil pengujian ketiga didapat hasil sebagai berikut:

\begin{tabular}{llc}
\multicolumn{2}{c}{ Tabel 13. Nilai Measurement of Sampling Adequacy III } \\
\hline No & \multicolumn{1}{c}{ Variabel-variabel yang diteliti } & Nilai MSA \\
1 & Pendidikan Pemilik & 0,830 \\
2 & Pelatihan Akuntansi & 0,878 \\
3 & Pengetahuan Akuntansi & 0,708 \\
4 & Pemberian Informasi Praktik Akuntansi & 0,829 \\
5 & Teknologi Informasi & 0,908 \\
6 & Kredit & 0,578 \\
7 & Minat & 0,762 \\
8 & Motivasi & 0,769 \\
9 & Kepribadian & 0,889 \\
10 & Komitmen Organisasi & 0,836 \\
11 & Cost Benefit & 0,501 \\
12 & Tingkat Persaingan & 0,721 \\
\hline
\end{tabular}

Sumber: Hasil Output SPSS yang diolah

Berdasarkan hasil analisis dari pengujian ketiga, nilai KMO MSA sebesar 0,799 dan Barlett's test menunjukkan signifikan dengan nilai 292,143 (sig. = 0,000) yang menunjukkan analisis dapat dilanjutkan.

Ekstraksi Faktor

Setelah menghitung matriks korelasi variabel, tahap selanjutnya adalah ekstraksi faktor. Ekstraksi faktor yaitu mengekstraksi faktor untuk mengetahui banyaknya faktor yang terbentuk. 
Penelitian ini menggunakan metode eigenvalues untuk menentukan banyaknya faktor. Hanya faktor-faktor yang memiliki eigenvalues $\geq 1$ yang dapat dipertahankan dalam model analisis faktor (Suliyanto, 2005).

Tabel 14. Ekstraksi Faktor

\begin{tabular}{lrrr}
\hline \multicolumn{4}{c}{ Total Variance Explained } \\
\hline \multirow{3}{*}{ Component } & Total & \% Varian & Cumulative \% \\
\hline 1 & $\mathbf{4 . 3 7 3}$ & 36.441 & 36.441 \\
2 & $\mathbf{1 . 3 2 9}$ & 11.078 & 47.519 \\
3 & $\mathbf{1 . 2 5 9}$ & 10.493 & 58.011 \\
4 & 0.991 & 8.257 & 66.268 \\
5 & 0.804 & 6.696 & 72.964 \\
6 & 0.658 & 5.487 & 78.451 \\
7 & 0.587 & 4.895 & 83.346 \\
8 & 0.521 & 4.340 & 87.686 \\
9 & 0.489 & 4.072 & 91.758 \\
10 & 0.446 & 3.717 & 95.475 \\
11 & 0.345 & 2.879 & 98.355 \\
12 & 0.197 & 1.645 & 100.000 \\
\hline Sumber: Hasil Output SPSS yang diolah &
\end{tabular}

Berdasarkan hasil dari output SPSS pada lampiran 8, tabel total variance explained menunjukkan bahwa dari proses ekstraksi faktor dihasilkan tiga faktor yang memiliki eigenvalues $\geq 1$. Tiga faktor tersebut dapat menyerap sebagian besar informasi yang terkandung dalam seluruh variabel asli atau bisa memberikan sumbangan terhadap varian seluruh variabel sebesar $58.011 \%$.

\section{Rotasi Faktor}

Hasil dari ekstraksi faktor dalam matriks faktor mengidentifikasikan hubungan antar faktor dengan variabel individual, namun dalam faktor-faktor tersebut banyak variabel yang berkorelasi sehingga sulit diinterpretasikan. Melalui tahap rotasi faktor matriks, faktor matriks dapat ditransformasikan ke dalam matriks yang lebih sederhana sehingga mudah diinterpretasikan. Penelitian ini menggunakan prosedur quartimax dalam merotasi faktor, yaitu metode rotasi faktor untuk meminimalisasi jumlah faktor yang digunakan untuk menjelaskan indikator.

Berdasarkan hasil rotasi faktor tabel rotated component matrix menunjukkan distribusi variabel-variabel yang telah di ekstrak ke dalam faktor yang telah terbentuk. Nilai factor loading menunjukkan tingkat keeratan suatu variabel dengan faktor yang terbentuk (Suprapto, 2004). Dengan demikian variabel dapat dimasukkan ke dalam faktor yang memiliki nilai factor loading terbesar, yaitu: 
Tabel 15. Faktor Terbentuk

\begin{tabular}{|c|c|c|c|}
\hline $\begin{array}{c}\text { Faktor } \\
\text { Terbentuk }\end{array}$ & Eigenvalues & Nama Variabel & $\begin{array}{c}\text { Factor } \\
\text { Loading }\end{array}$ \\
\hline \multirow{9}{*}{ Faktor 1} & \multirow{9}{*}{4,373} & Pendidikan & 0,597 \\
\hline & & Pelatihan Akuntansi & 0,658 \\
\hline & & Pengetahuan Akuntansi & 0,475 \\
\hline & & Pemberian Informasi Praktik Akuntansi & 0,721 \\
\hline & & Teknologi Informasi & 0,774 \\
\hline & & Minat & 0,773 \\
\hline & & Motivasi & 0,799 \\
\hline & & Kepribadian & 0,566 \\
\hline & & Komitmen Organisasi & 0,666 \\
\hline \multirow{2}{*}{ Faktor 2} & \multirow{2}{*}{1,329} & Cost Benefit & 0,868 \\
\hline & & Tingkat Persaingan & 0,565 \\
\hline Faktor 3 & 1,259 & Kredit & 0,850 \\
\hline
\end{tabular}

Sumber: Hasil Output SPSS yang diolah

Hasil dari rotasi faktor menunjukkan semua variabel memiliki factor loading $>0,4$ maka seluruh faktor dapat dianalisis lebih lanjut ke tahap selanjutnya yaitu interpretasi faktor.

Faktor 1 merupakan faktor yang paling berpengaruh terhadap praktik akuntansi pada usaha kecil dan menengah karena memiliki eiginvalues terbesar yakni 4,373. Seperti yang dapat dilihat pada tabel 23, variabel yang termasuk ke dalam faktor ini adalah variabel pendidikan dengan nilai factor loading sebesar 0,597, pelatihan akuntansi sebesar 0,658, pengetahuan akuntansi sebesar 0,475 , pemberian informasi praktik akuntansi sebesar 0,721 , teknologi informasi sebesae 0,774 , minat sebesar 0,773, motivasi sebesar 0,799, kepribadian sebesar 0,566 dan komitmen organisasi sebesar 0,666.

Faktor 2 mempunyai eigenvalues sebesar 1,329 dan variabel-variabel yang termasuk kedalam faktor ini adalah variabel cost benefit dengan factor loading sebesar 0,868 dan variabel tingkat persaingan sebesar 0,565.

Faktor 3 mempunyai eigenvalues sebesar 1,259 dan variabel yang masuk kedalam faktor ini adalah variabel kredit dengan factor loading sebesar 0,850.

Interpretasi Faktor

Peneliti menggunakan cara yang pertama untuk memberikan nama pada faktor yang terbentuk. Faktor-faktor yang dihasilkan dapat diberi nama sebagai berikut: 1) Faktor 1 terdiri dari variabel pendidikan, pelatihan akuntansi, pemberian informasi praktik akuntansi, teknologi informasi, minat, motivasi, komitmen organisasi dan kepribadian. Variabel pendidikan mempunyai indikator pendidikan formal terakhir yang ditempuh oleh pemiliki atau manajer UKM. Variabel pelatihan akuntansi mempunyai indikator frekuensi pelatihan yang pernah diikuti leh pelaku atau manajer UKM. Variabel pengetahuan akuntansi memiliki indikator pengetahuan deklaratif dan pengetahuan procedural. Variabel pemberian informasi praktik akuntansi 
memiliki indikator tingkat perolehan informasi terkait dengan praktik akuntansi dan berkaitan dengan seberapa penting informasi yang didapatkan untuk kelangsungan usahanya. Variabel teknologi informasi mempunyai indikator kemudahan dan efektivitas. Variabel minat memiliki indikator kebutuhan, dorongan dan keinginan. Variabel motivasi mempunyai indikator usaha atau intensitas dan pengorbanan waktu dan biaya dalam mempelajari akuntansi. Variabel komitmen organisasi mempunyai indikator melakukan upaya penyesuaian, meneladani kesetiaan, mendukung secara aktif dan melakukan pengorbanan pribadi. Sedangkan variabel kepribadian memiliki indikator kepercayaan kepada diri sendiri, ketahanan menghadapi cobaan, berani dalam mengambil resiko, kepemimpinan dan berorientasi masa depan. Pemberian nama pada faktor 1 yang telah terbentuk adalah dengan menggunakan cara yang pertama, yakni dengan memberikan nama faktor yang dapat mewakili nama-nama variabel yang membentuk faktor tersebut. Oleh karena itu, faktor 1 diberi nama Faktor Pengetahuan dan Kepribadian. 2) Faktor 2 terdiri dari variabel cost and benefit dan tingkat persaingan. Variabel cost benefit memiliki indikator besarnya manfaat yang didapatkan oleh pelaku jika dibandingkan dengan biaya yang dilkeluarkan. Variabel tingkat persaingan mempunyai indikator iklim yang kondusif, keunggulan kompetitif dan keunggulan kompetitif.. Pemberian nama pada faktor 2 yang telah terbentuk dilakukan dengan memberikan nama faktor yang dapat mewakili nama-nama variabel yang membentuk faktor Oleh sebab itu, faktor 2 diberi nama Faktor Kegunaan. 3) Faktor 3 terdiri dari variabel kredit. Variabel kredit mempunyai indikator jumlah pemberian kredit, jangka waktu kredit dan bunga kredit.. Pemberian nama pada faktor 3 yang telah terbentuk adalah dengan memberikan nama faktor yang dapat mewakili nama variabel yang membentuk faktor. Oleh karena itu, faktor 1 diberi nama Faktor Kredit.

\section{KESIMPULAN}

Terdapat tiga faktor yang mempengaruhi praktik akuntansi pada usaha kecil dan menengah di Kabupaten Kebumen, yakni: a) Faktor pengetahuan dan kepribadian terdiri dari variabel pendidikan, pelatihan akuntansi, pemberian informasi praktik akuntansi, minat, motivasi, dan kepribadian. b) Faktor kegunaan terdiri dari variabel cost benefit dan tingkat persaingan. c) Faktor kredit terdiri dari variabel kredit. d) Faktor yang paling mempengaruhi praktik akuntansi pada usaha kecil dan menengah di Kabupaten Kebumen adalah faktor pengetahuan dan kepribadian yang memiliki eigenvalues terbesar yakni 4,373. 


\section{DAFTAR PUSTAKA}

Amoako, Gilbert Kwabena. (2013). Accounting Practices of SMEs: A Case Study of Kumasi Metrpolis in Ghana. International Journal of Business and Management; Vol. 8, No. 24.

Hidayat, Imam P. (2008). Akuntansi untuk UKM. http://imanph.wordpress.com/2008/10/21/akuntansi-utk-ukm-juli-2004/ diakses pada 14 Februari 2017.

Holmes, S., \& Nicholls, D. (1988). An analysis of the Use of Accounting Information by Australian Small Business. Journal of Small Business Management, 26 (2), 57 - 69.

IAI. (1994). Standar Akuntansi Keuangan. Ed 1 \& 2. Jakarta: Salemba Empat.

Ikatan Akuntan Indonesia. (2009). Standar Akuntansi Keuangan. PSAK. Jakarta: Salemba Empat.

Indriyo G dan I. Nyoman. (1997). Manajemen Sumber Daya Manusia. Yogyakarta: BPFE.

Jogiyanto. (1999). Pendekatan Terstruktur Teori dan Praktek Aplikasi Bisnis. Yogyakarta: Andi Offset.

Kieso, Donald E., Jerry J, Weygantdt. (2007). Akuntansi Intermediete. Erlangga. Jakarta.

Krisdiartiwi, Mamik. (2008). Pembukuan Sederhana untuk UKM. Yogyakarta: Media Pressindo.

Loderer, Claudio and Urs Waelchli. (2010). Firm age and performance. Munich Personal RePEc Archive. University of Bern. Euroope.

Lucie, Setiana. (2005). Teknik Penyuluhan dan Pemberdayaan Masyarakat. Bogor: Ghalia Indonesia.

Marbun, B.N. (1997). Manajemen Perusahaan Kecil. PT Pustaka Binaman Pressindo. Jakarta.

Marfuah, dan Maricha Ulfa. (2014). Pengaruh Intellectual Capital terhadap Profitabilitas, Produktivias dan Pertumbuhan Perusahaan Perbankan. Jurnal Ekonomi dan Bisnis Islam. Vol. IX, No. 1.

Maseko, Nelson dan Onias Manyani. (2011). Accounting Practices of SMEs in Zimbabwe: An Investigative Study of Record Keeping for Performance Measurement (A case study of Bindura). Journal of Accounting and Taxation Vol. 3(8).

Moore, CW, Justin G Longenecker and J William Petty. (2001). Kewirausahaan. Jakarta: Salemba Empat. Jakarta.

Narsa, I Made, Agus Widodo dan Sigit Kurnianto. (2012). Mengungkap Kesiapan UMKM dalam Implementasi Standar Akuntansi Keuangan Entitas Tanpa Akuntabilitas Publik (PSAK-ETAP) untuk Meningkatkan Akses Modal Perbankan. Majalah Ekonomi. No. 3.

Rudiantoro, Rizki dan Sylvia Siregar, Veronica. (2011). Kualitas Laporang Keuangan UMKM serta Prospel Implementasi SAK ETAP. Simposium Nasional Akuntansi XIV Universitas Syiah Kuuala Banda Aceh.

Spilker, BC. (1995). The Effect of Time Pressure and Knowledge on Key Word Selection Behavior in Tax Research. The Accounting Review Vol. 70, No. 1 Pp. 49-70.

Sugiyono. (2009). Metode Penelitian Bisnis: Pendekatan Kuantitatif, Kualitatif dan R\&D. Bandung: CV Alfabeta. 
Suhairi, Sofri Yahya, dan Hasnah Haron, (2004). Pengaruh Pengetahuan Akuntansi dan Kepribadian Wirausaha terhadap Penggunaan Informasi Akuntansi dalam Pengambilan Keputusan Investasi. Simposium Nasional Akuntansi VII. Denpasar.

Sujanto, Agus., Halem Lubis, dan Taufik Hadi. (2006). Psikologi Kepribadian. Jakarta: Bumi Aksara.

Suliyanto. (2005). Analisis Data dalam Aplikasi Pemasaran. Penerbit Ghalia Indonesia. Bogor.

Supranto, J. (2004). Analisis Multivariat: Arti dan Interpretasi. PT Rineka Cipta, Jakarta.

Suryana. (2000). Ekonomi Pembangunan Problematika dan Pendekatan. Jakarta: Salemba Empat.

Suwardjono. (2002). Teori Akuntansi (Perekayasaan Laporan Keuangan). Yogyakarta. BPFE.

Swasta, DH, Sukotjo W, Ibnu. (2004). Pengantar Bisnis Modern. Yogyakarta: Liberty.

Warren \& Roucek. (1962). Sociology, An Introduction. London: Patterson Littlefield \& Adams.

Widarjono, Agus. (2015). Analisis Multivariat Terapan. Penerbit UPP STIM YKPN. Yogyakarta.

Widyastuti, Widyawati, dkk. dan Juliana. (2004). Pengaruh Motivasi terhadap Minat Mahasiswa Akuntansi untuk Mengikuti Pendidikan Profesi Akuntansi. Simposium Nasional Akuntansi VII.

Wijaya, Tony. (2010). Analisis Multivariat. Penerbit Universitas Atma Jaya Yogyakarta, Yogyakarta.

Wursanto. (2002). Dasar-dasar Ilmu Organisasi. Jakarta: Binarupa Aksara

Zamani, Mukhammad. (2010). Pengaruh Motivasi, Minat, dan Kepribadian terhadap Persepsi Implementasi Standar Akuntansi Keuangan Entitas Tanpa Akuntabilitas Publik (SAK ETAP) pada Usaha Kecil Menengah (UKM) di Kabupaten Banyumas. Skripsi. Program Sarjana Universitas Jenderal Soedirman. Purwokerto. (Tidak dipublikasikan). 